\title{
Herpes Simplex Virus Type 1/Adeno-Associated Virus Hybrid Vectors
}

\author{
Anna Paula de Oliveira and Cornel Fraefel ${ }^{*}$
}

Institute of Virology, University of Zurich, Zurich, Switzerland

\begin{abstract}
Herpes simplex virus type 1 (HSV-1) amplicons can accommodate foreign DNA of any size up to $150 \mathrm{kbp}$ and, therefore, allow extensive combinations of genetic elements. Genomic sequences as well as cDNA, large transcriptional regulatory sequences for cell type-specific expression, multiple transgenes, and genetic elements from other viruses to create hybrid vectors may be inserted in a modular fashion. Hybrid amplicons use genetic elements from HSV-1 that allow replication and packaging of the vector DNA into HSV-1 virions, and genetic elements from other viruses that either direct integration of transgene sequences into the host genome or allow episomal maintenance of the vector. Thus, the advantages of the HSV-1 amplicon system, including large transgene capacity, broad host range, strong nuclear localization, and availability of helper virus-free packaging systems are retained and combined with those of heterologous viral elements that confer genetic stability to the vector DNA. Adeno-associated virus (AAV) has the unique capability of integrating its genome into a specific site, designated AAVS1, on human chromosome 19. The AAV rep gene and the inverted terminal repeats (ITRS) that flank the AAV genome are sufficient for this process. HSV-1 amplicons have thus been designed that contain the rep gene and a transgene cassette flanked by AAV ITRs. These HSV/AAV hybrid vectors direct site-specific integration of transgene sequences into AAVS1 and support long-term transgene expression.
\end{abstract}

Keywords: HSV-1 amplicon vectors, adeno-associated virus, herpes simplex virus type 1, hybrid vectors.

\section{HERPES SIMPLEX VIRUS TYPE 1 - BIOLOGICAL PROPERTIES}

Herpes simplex virus type 1 (HSV-1) is a member of the family Herpesviridae, subfamily Alphaherpesvirinae, genus Simplexvirus. It is a common human pathogen that causes infections of the orofacial mucosal surfaces and may rarely cause acute hepatitis, kerato-conjunctivitis or meningoencephalitis.

The HSV-1 particle is composed of three different compartments, capsid, tegument, and envelope. The capsid proteins are involved in the formation and maturation of the icosahedral capsid [1] and packaging of the viral genome [26]. The tegument, which is located between capsid and envelope, is composed of viral proteins involved in transport of capsids to nuclear pores, attachment to the nuclear pore complex [7], release of the virus genome from the capsid into the nucleus [8], and remodeling the host cell environment to optimize replication [9-14]. The viral envelope is a lipid bilayer of host origin that contains 11 viral glycoproteins. These play important roles in viral attachment, entry, cell to cell spread, and egress $[15,16]$. HSV-1 can enter the cells by receptor-mediated fusion between virus and cell membrane [17-20]. However, depending on the cell type and virus strain, HSV-1 can penetrate the host cell also by endocytosis [20-22] and phagocytosis [23]. In the cytoplasm, the capsid is transported to the nucleus via interactions with the minus-end-directed microtubule motor protein dynein [24-26] Capsids bind to the nuclear pore complex and release the DNA genome into the nucleus [7, 27, 28].

*Address correspondence to this author at the Institute of Virology, University of Zurich, 8057 Zurich, Switzerland; Tel: +41 44635 8713, Fax: +41 44635 8911; E-mail: cornel.fraefel@access.uzh.ch
The HSV-1 genome is a double-stranded DNA (dsDNA) of $152 \mathrm{kbp}$. It is organized in two segments, unique long (UL) and unique short (US), both of which are flanked by inverted repeats (see Fig. 1). The essential cis elements for viral DNA replication and encapsidation include the origins of DNA replication, located in the UL (ori $\mathrm{L}_{\mathrm{L}}$ ) and $\mathrm{TR}_{\mathrm{s}}$ ( ori $_{\mathrm{S}}$ ) regions $[29,30]$, and the packaging/cleavage signals (pac) that reside in the $a$ sequences located at both termini of the genome as well as at the junction between the long and the short segments [31]. The viral genome circularizes after it reaches the nucleus [32] and serves as a template for DNA replication. However, there is also evidence that circularization is not required for replication [33]. The majority of the replicative intermediates are long concatemers that are thought to have been synthesized by a rolling-circle mechanism [34-36]. The concatemers are cleaved into unit-length genomes at the pac signals after filling pre-formed capsids [36, 37].

HSV-1 encodes approximately 89 genes [38], which are expressed in a cascade of three temporal phases: immediateearly, early, and late. The late genes can be subdivided in leaky-late (expression is not dependent on viral DNA synthesis) and true-late (expression depends on viral DNA synthesis) $[31,39,40]$.

There are several hypotheses on the mechanisms of envelopment of the nucleocapsid. The generally accepted view suggests a two-step envelopment process in which the capsid acquires a primary envelope by budding at the inner nuclear membrane and then is de-enveloped by fusion with the outer nuclear membrane [41, 42]. The secondary envelope is acquired when the capsid buds into the Golgi or cytoplasmic vesicles [43-49]. The alternative pathways described include (i) budding at the inner nuclear membrane followed by intraluminal transport via ER and Golgi and (ii) 


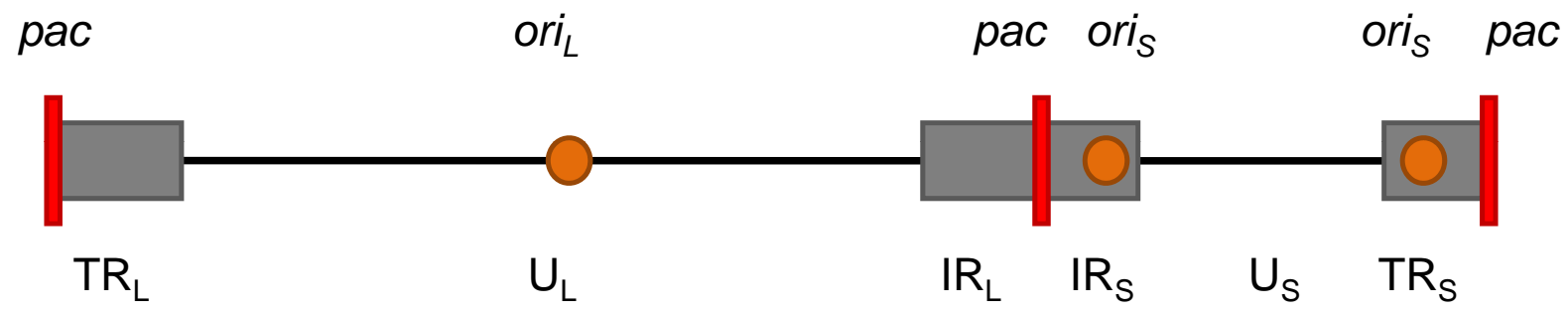

Fig. (1). Schematic representation of the HSV-1 genome. The HSV-1 genome is a linear double stranded DNA of approximately $152 \mathrm{~kb}$ in size, composed of two unique segments, $\mathrm{U}_{\mathrm{L}}$ and $\mathrm{U}_{\mathrm{S}}$, which are flanked by inverted repeats, $\mathrm{TR}_{\mathrm{L}} / \mathrm{IR}_{\mathrm{L}}$ and $\mathrm{IR}_{\mathrm{S}} / \mathrm{TR}_{\mathrm{S}}$. The minimal cis elements required for HSV-1 DNA replication and packaging include the origin of DNA replication, ori, and the cleavage/packaging, pac, signals.

exit via impaired nuclear pores and envelopment at the outer nuclear membrane or ER membrane [50-52]. Regardless of the mechanism of envelopment, mature virions seem to exit the cell by exocytosis via intraluminal transport to Golgi cisternae and formation of transport vacuoles [53-55].

An important aspect of HSV-1 biology is the capability of this virus to establish latent infections in sensory neurons of the trigeminal ganglia [56]. The latent HSV-1 genome is a circular, condensed episome, and viral gene expression is limited to the non-coding, latency-associated transcripts (LATs) [57]. Expression of LATs was demonstrated to increase the number of neurons in which latency is established [58] and to affect the efficiency of reactivation $[59,60]$. Recent findings that LAT encodes several micro RNAs (miRNA) in HSV-1 infected cells corroborates with the proposed hypothesis that the exonic regions of LAT might function as primary miRNA precursors [61]. At least two of the identified miRNA precursors in latently infected neurons may facilitate the establishment and maintenance of viral latency by post-transcriptionally regulating viral gene expression [62-65].

Latent HSV-1 can periodically reactivate in response to a variety of stimuli, including fever, UV light, hormonal imbalance, malignancy or immune suppression, and enter a new lytic cycle, usually at the site of the primary infection. Recently, the requirement of ICP0 for viral DNA replication [66-68] and for exit from latency has been reconsidered, as in vivo studies showed that reactivation of HSV-1 genomes does not depend on viral DNA amplification [69] nor functional ICP0 [70]. Upon stress conditions, and in the absence of other viral proteins, VP16 was demonstrated to be activated [71], supporting the hypothesis that de novo expression of VP16 regulates entry into the lytic program in neurons. Repeated reactivation does not appear to kill the neurons, indicating that the extent of virus replication must be limited.

The understanding of the biological properties of HSV-1 and the molecular mechanisms of virus replication have allowed the design of specialized vector systems for somatic gene therapy, oncolytic virotherapy, and vaccination.

\section{HSV-1 BASED VECTOR SYSTEMS}

HSV-1 is an attractive vector for gene therapy due to its (i) large transgene capacity, (ii) high transduction efficiency and broad cell tropism that includes both dividing and nondividing cells, and (iii) ability to establish latency while maintaining at least some transcriptional activity. However, as HSV-1 is a human pathogen, its use as a vector can result in host immune responses and cytopathogenic effects in patients, and possibly reactivation of and recombination with latent wild-type HSV-1. Taking these aspects into consideration, two different HSV-1-based vector systems, recombinant and amplicon, have been developed.

Initially, recombinant herpesviruses were constructed for functional studies of viral genes and development of vaccines. However, advances in site-specific modification of the viral genome facilitated the use of HSV-1 as a gene transfer vehicle [72]. Different approaches for the construction of recombinant HSV-1 vectors are based on the target tissue and purpose of gene delivery e.g. replicationconditional recombinant HSV-1 vectors are suitable for therapeutic treatment of tumors; replication-defective recombinant HSV-1 vectors are applied for gene replacement therapy [73]. Although some preclinical studies show promising results, several obstacles have to be overcome: (i) replication-defective mutants of HSV-1 can cause cytopathic effects in primary cultures of neuronal cells and inflammatory responses in neural tissue in vivo; (ii) most viral and nonviral promoters are silenced after injection into the brain. Therefore, the main focus in the development of new HSV-1-based vectors has been directed at achieving nontoxic, long-term gene expression in neurons.

The second type of HSV-1-based vector system, the HSV-1 amplicon vector, originated about three decades ago. Spaete and Frenkel analyzed the nature of defective virus genomes generated during the passage of standard HSV-1 stocks at high multiplicity of infection [74, 75]. Their investigations revealed that an ori and a pac signal were the only two cis-acting sequences required for the replication and packaging of defective virus genomes in the presence of trans-acting HSV-1 helpervirus (Fig. 2A). The word amplicon was used to delineate the fact that multiple copies of a DNA sequence of interest can be amplified in a head-totail arrangement in concatemeric defective virus genomes and packaged into HSV virions [76]. HSV-1 amplicon vectors share similar structural and immunological properties with the wild type HSV-1 particle, which can trigger cell signaling and cellular responses that may have a transient impact on cell homeostasis or gene expression. However, the lack of virus genes and protein synthesis reduces the risk of reactivation, complementation and recombination with latent or resident HSV-1 genomes.

HSV-1 amplicon vectors have been used to infect efficiently a number of different cell types, including 

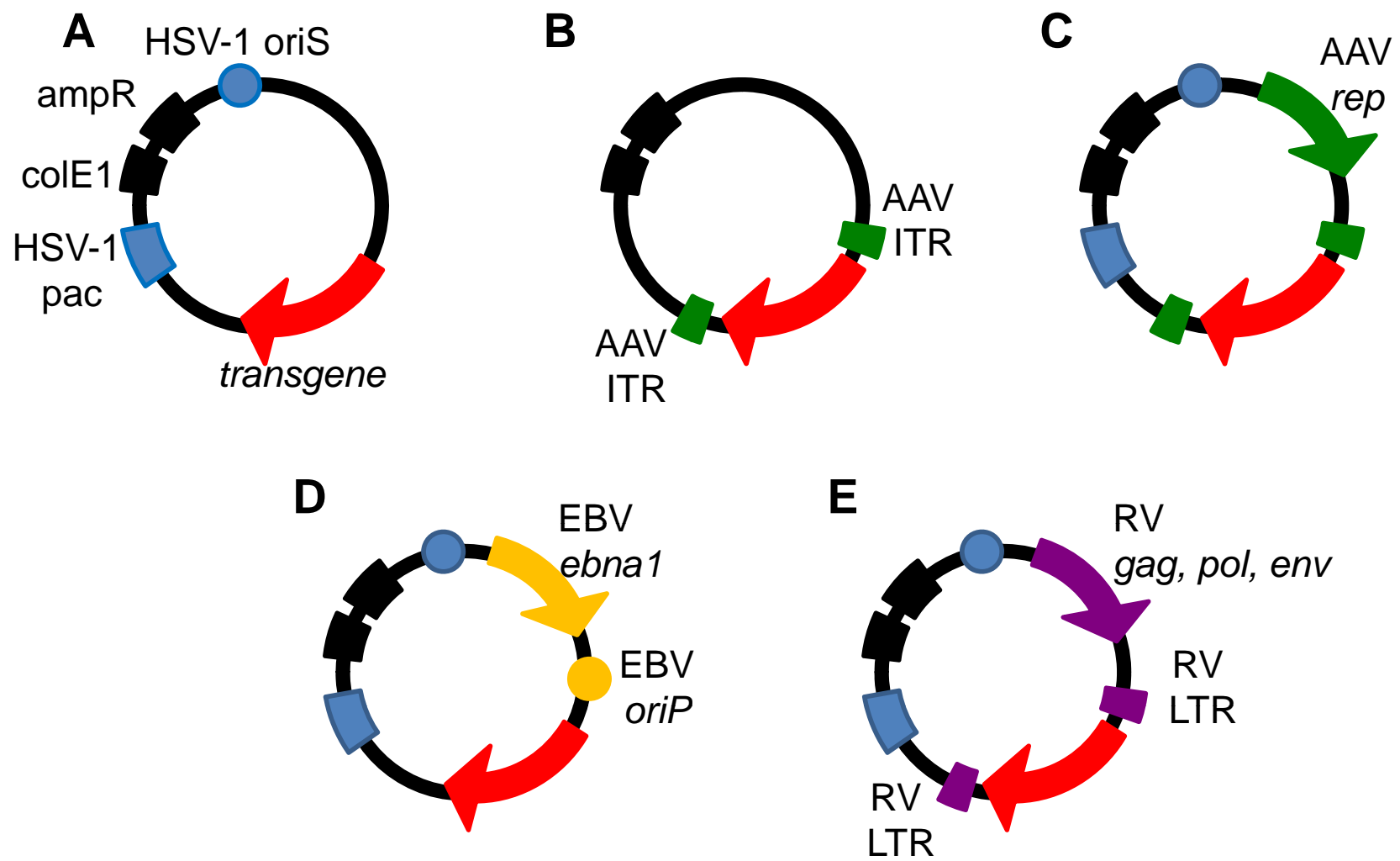

Fig. (2). Viral vectors. A) HSV-1 amplicon. The HSV-1 amplicon contains three types of genetic elements: i) sequences from bacteria (colE1 and ampR) that allow plasmid propagation in E. coli; ii) sequences from HSV-1, in particular an origin of DNA replication (ori) and a DNA packaging/cleavage signal ( $\mathrm{pac}$ ), which allow replication and packaging of the amplicon DNA into HSV-1 particles in the presence of HSV-1 helper functions in mammalian cells; and iii) a transgene cassette with the gene of interest. B) Recombinant AAV vector. Recombinant AAV vectors are bacterial plasmids that contain the AAV ITRs flanking a transgene of interest. Replication of the ITR cassette and packaging into AAV particles is achieved by supplying helpervirus functions and the rep and cap genes in cis or trans but outside the ITR cassette. C) HSV/AAV hybrid amplicon. In addition to the HSV-1 amplicon elements, HSV/AAV hybrid amplicon vectors contain the AAV rep gene and a transgene of interest flanked by AAV ITRs. D) HSV/EBV hybrid amplicon. In addition to the HSV-1 amplicon elements, HSV/EBV hybrid amplicon vectors contain the EBV origin of DNA replication (oriP) and the gene encoding EBNA-1 which together can support episomal retention and segregation of the vector in dividing cells. E) HSV/RV hybrid amplicon. In addition to the HSV-1 amplicon elements, HSV/RV hybrid amplicon vectors contain the retrovirus (MoMLV) gag, pol, and env genes, and the RV LTRs flanking a transgene of interest.

epidermal cells and dendritic cells in the skin [77, 78], some cell types in the cochlea [79, 80], hepatocytes [81], skeletal muscle [82], neurons [83], glioblastoma, and other tumor cells [84-86]. Despite the promising features of the HSV-1 amplicon vector as a gene delivery system, further developments concerning vector production, stability of transgene expression, and interaction with target cells are essential. Recently, the presence of bacterial sequences in the amplicon genome was shown to be responsible for the formation of inactive chromatin, leading to a rapid transgene silencing [87]. Strategies to increase the stability of transgene expression included the use of: (i) cell typespecific promoters $[88,89]$ and (ii) genetic elements from other viruses that confer genetic stability, such as integration of the transgene into host chromosomes [90, 91] or conversion of the amplicon genome into a replicationcompetent extrachromosomal element [92-95].

One of these strategies, the combination of genetic elements from HSV-1 amplicons and adeno-associated virus (AAV) to achieve site-specific integration of the transgene into the host genome and long-term transgene expression is described in detail below, after a short introduction into AAV biology.

\section{ADENO-ASSOCIATED VIRUS - BIOLOGICAL PROP- ERTIES}

Adeno-associated virus (AAV) belongs to the genus Dependovirus within the subfamily Parvovirinae, family Parvoviridae [96]. Different AAV serotypes have been identified that can infect a broad range of species; about 11 serotypes and more than 100 variants of AAV infect primates. Based on serological studies, AAV serotypes 2, 3, and 5 most probably have a human origin [97, 98], while AAV4 appears to have originated in monkeys [99]. AAV6 shares some genomic similarities with AAV2 and AAV1, raising the hypothesis that a recombination event could have occurred in vivo or in cell culture [100, 101]. The AAV serotypes 1 to 6 were isolated as contaminants in laboratory adenovirus stocks, while AAV 7, 8, 9, 10, and 11 were isolated as DNA molecules using a "signature PCR", a 
screening-based strategy [102]. Despite being widespread among species and infecting different tissues, AAV infections have not been associated with any pathology. Primate AAV serotypes share significant sequence similarities, and the occurrence of cross-reaction of neutralizing antibodies may be species specific or depend on tissue type or route of administration [101, 103, 104].

The genome of AAV is a linear single stranded DNA of $4.7 \mathrm{~kb}$, and either the positive or negative strand can be packaged with equal efficiency. The genome is flanked by inverted terminal repeats (ITR) of $145 \mathrm{bp}$, containing a palindromic sequence that forms a hairpin as a T-shaped secondary structure. The Rep binding site (RBS) and the terminal resolution site (TRS) are regions within the ITRs that play important roles in the replication and packaging of the AAV genome [105] (Fig. 3A). Two open reading frames (ORFs), Rep and Cap, are responsible for encoding overlapping proteins through alternative splicing (Fig. 3B). The Rep proteins, Rep78/68, and Rep52/40 are transcribed from two different promoters, $\mathrm{p} 5$ and $\mathrm{p} 19$, respectively, and are involved in DNA replication, transcription, and chromosomal integration. The $\mathrm{p} 5$ promoter contains a TATA box, a RBS, a TRS, the Yin Yang 1 (YY1) binding site, and a downstream sequence that can form a hairpin structure. The RBS is involved in Rep-mediated promoter regulation activity $[106,107]$, thus in the absence of helper functions small amounts of Rep are expressed that bind to the $\mathrm{p} 5$ promoter inhibiting transcription [108, 109]. The regulatory activity of Rep seems to be involved in the maintenance of a constant ratio of Rep and Cap proteins during infection in order to keep the balance between AAV genome replication and packaging. The Cap ORF encodes three overlapping proteins, VP1, VP2 and VP3, from a single promoter, $\mathrm{p} 40$. These structural proteins compose the AAV icosahedral capsid whose diameter ranges from 18 to $26 \mathrm{~nm}$ [110].

A

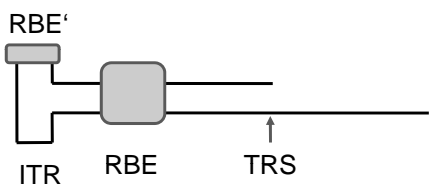

B

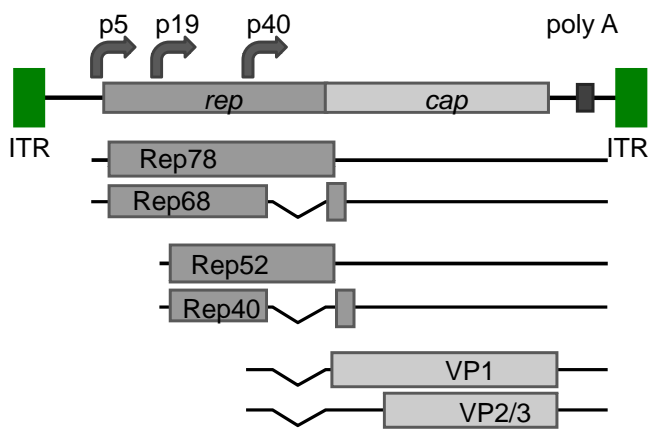

Fig. (3). Schematic map of the wild type AAV genome. A) Secondary structure formed by the inverted terminal repeat, ITR. Depicted are the Rep binding sites, RBEs, and the terminal resolution site, TRS. B) The AAV genome expresses two clusters of genes, rep and cap, from three different promoters, p5, p19, p40, by alternative splicing.
The replication of the AAV genome is based on a "rolling hairpin model". The hairpin structure at the ITR acts as a primer that converts the DNA into a double-stranded template, and together with the essential cis-acting elements RBS and TRS, and helpervirus functions, the replication and transcription of the AAV genome is initiated [111-113]. The Rep78/68 proteins play major roles in the replication process due to DNA-binding, endonuclease, and helicase activities. After binding to the RBS, Rep induces a site- and strandspecific nick at the TRS, creating a new genome end allowing the reinitiation of the synthesis and formation of a monomer extended form that can be packaged [114]. If the hairpin structure in the monomer turnaround form is not resolved before reinitiation on the other genome end, continued synthesis leads to double stranded dimer molecules, in which two genomes in the inverted orientations (head-to-head or tail-to-tail) are covalently joined by a single ITR [115]. Interestingly, the RBS and TRS signals located within the $\mathrm{p} 5$ promoter sequence have been demonstrated to act together as an alternative origin of DNA replication in the presence of adenovirus $[116,117]$ or HSV-1 helpervirus functions [108]. Replication from a plasmid cloned $\mathrm{p} 5$ replication origin led to the accumulation of large, head-to-tail linked concatameric replication products, which could readily be packaged into HSV-1 virions if the HSV-1 packaging/cleavage signal was included on the plasmid [108]. These findings indicate that the AAV p5 replication origin could substitute for the HSV-1 origin of DNA replication on HSV/AAV hybrid vectors (see below). AAV is a replication defective virus as it depends on a helper virus, such as adenoviruses [118], a herpesvirus [119121], or vaccinia virus [122] for productive replication (Fig. 4). Helper viruses are also responsible for inducing a cell cycle arrest in late S or G2 phase, as in the case of adenoviruses [123] or for down regulating host cell functions as in the case of HSV-1 as the helpervirus [124, 125].

Many studies have assessed the different elements from the helperviruses required for AAV replication. A model has been proposed where the HSV-1 helicase/primase proteins constitute a scaffold that recruits ICP8, Rep and cellular replication (RPA) proteins to the self-primed AAV DNA into replication compartments [126-129]. The HSV-1 polymerase complex is preferentially used for AAV replication instead of the cellular machinery $[113,130]$. Interestingly, an inhibitory effect of Rep78/68 proteins has been described on HSV-1 replication [131, 132], suggesting a regulatory effect of AAV over HSV-1, thereby limiting expression of HSV-1 early genes [113, 129].

In the absence of helpervirus, the AAV genome can integrate into a specific site termed AAVS1, on chromosome 19q13.3-qter of human cells [133-136] (Fig. 4). The integration is mediated by Rep78/68 and ITRs through a nonhomologous deletion/insertion recombination event [134, 136-143]. Also, an integration efficiency element (IEE) has been identified within the p5 promoter of AAV [144], and more specifically a 16-bp RBE was shown to be sufficient for AAV genome integration [145]. Rescue of the integrated AAV genome is possible by superinfection with helper virus [130]. Although HSV-1 ICP0 seems to contribute to the activation of the rep gene from latent AAV genomes [146], 


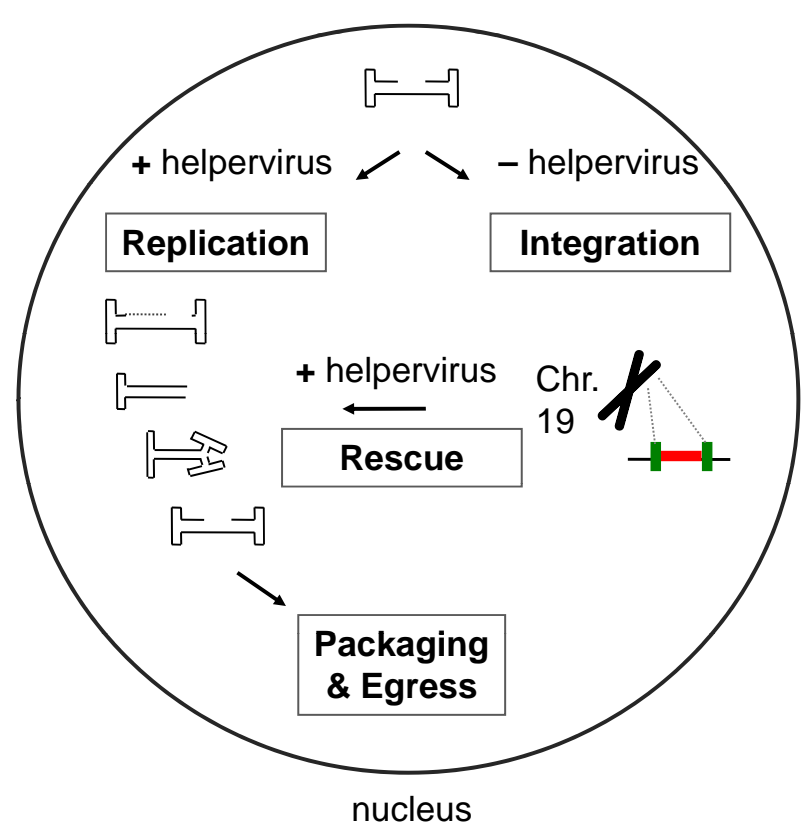

Fig. (4). The life cycle of AAV. Co-infection of AAV and helpervirus, adenovirus or HSV-1, leads to viral gene expression, viral DNA replication, and production of progeny virus. In the absence of helpervirus, the genome of AAV can integrate into a specific site on human chromosome 19. In the presence of helpervirus, integrated AAV genomes are rescued and enter the lytic replication cycle.

it is not sufficient to induce rep synthesis [130]. Some studies have demonstrated the autonomous replication of AAV under special conditions [147-149], however, the efficiency of replication is significantly lower than in presence of helpervirus functions.

AAV can infect different tissues and bind to unique cellular receptors, which can account for a serotype-specific tissue tropism. Several cellular receptors used by AAV for cell entry have been identified, including heparan sulfate [150], fibroblast growth factor receptor [151], and integrin alphaVbeta5 [152]. The initial steps of AAV infection, attachment to cellular glycosaminoglycan receptors and interactions with coreceptors seem to define the intracellular trafficking pathway of the capsid. Upon entry, AAV capsids are endocytosed via clathrin-coated pits [153], a process that requires dynamitin [154], and transported through both late and recycling endosomes. Trafficking in recycling endosomes appears to be favorable for efficient transgene expression [155]. The process of uncoating is still not well characterized [153, 156], however, AAV appears to enter the nucleus through a mechanism independent of the nuclear pore complex [157].

\section{AAV BASED VECTORS}

The broad cell tropism, lack of pathogenicity, and stable long-term gene expression make AAV an attractive vector for gene therapy [158]. AAV2 was the first AAV isolate to be developed into a recombinant vector for transgene delivery as it has been shown to infect a broad range of cell types in animal models [159], showing high efficiency in most of the tumor cells tested [160]. Recombinant AAV vectors are constructed by replacing the Rep and Cap ORFs with a transgene of interest flanked by the ITRs. Rep, Cap and helper functions can be supplied in trans in order to allow replication of the transgene in the host cell [135] (Fig. 2B). Different methods of delivering helper functions have evolved, from co-infection with Ad or HSV-1 [161, 162], to plasmid-based protocols [163], and stable-expression by cell lines [164-166]. The development of a baculovirus based vector production method in insect (SF9) cells has also shown promising results $[167,168]$.

Recombinant AAV vectors have been tested in preclinical studies for a variety of diseases such as hemophilia, $\alpha-1$ anti-trypsin deficiency, cystic fibrosis, Duchenne muscular dystrophy, rheumatoid arthritis, prostate and melanoma cancer, Canavan disease [169], Alzheimer's, and Parkinson's [170].

Recombinant AAV have shown efficient transduction of different regions of the brain, and are currently used in several clinical trials for neurological disorders [171-173]. Increased interest in designing AAV vectors for the treatment of neurodegenerative diseases that require gene delivery to broad areas or very local and specific areas of the brain are now the focus of many studies [174]. AAV2 has been the most widely used AAV serotype for gene delivery to the CNS, transducing almost exclusively neurons in different brain structures [175178], and supporting long-term transgene expression in the CNS [179-181] as well as in the dorsal root ganglia [182]. AAV2 has shown higher transduction efficiency in glioblastoma in vitro and in vivo when compared to serotypes 4 and 5 [183]. However, other studies have demonstrated a higher distribution and transduction in the CNS when using rAAV serotypes 1 and $5[175,184,185]$. The different AAV serotypes have been exploited on their ability to efficiently transduce distinct regions of the brain due to different cellular tropisms $[174,183,186]$.

\section{Immune Response to rAAV Vectors}

The brain has been thought to be an immune privileged, compartmentalized organ that lacks an adaptive immune response. Some studies have suggested that viral vectors induce little immunogenicity, especially when injected once in the parenchyma of naïve animals [104, 187, 188], or that the presence of antibodies to both capsid proteins and transgene products seems not to correlate with reduction in transgene expression [187, 188]. Further studies with preimmunized animals, however, established that circulating neutralizing antibodies can affect intracerebral rAAVmediated transduction, and even suggested that the adaptive arm of the immune system can be primed by intracerebral rAAV2 administration [104].

Immune responses in the absence of expression of AAV genes have also been observed in naïve animals in a dosedependent manner [104]. This has been suggested to occur due to the slow process of AAV capsid uncoating, thus allowing antigen presentation of processed capsid peptides by MHC-I, or by an immune reaction specific to the transgene [189, 190].

\section{Improvements on rAAV Vectors}

Despite the explicit advantages of rAAV as a vector for gene therapy, improvements in the regulation of transgene expression need to be achieved in order to confer safety. 
Much research is focused on efforts to limit vector spread, in order to achieve specific tissue or organ delivery, or to enable the transduction of tissues that are refractory to naturally occurring AAV vectors. Engineering of AAV vectors for altered tropism, enhanced transduction efficiency, and evasion of antibody neutralization includes manipulation of the AAV capsid by insertion of peptide ligands, conjugate-based targeting, and presentation of large protein ligands on the AAV capsid [191]. The diversity of AAV serotypes brings the possibility to evade preexisting immunity by engineering hybrid or pseudotyped AAV vectors derived from different serotypes [192-194].

Another strategy that focuses on the transduction efficiency is the improvement on the second-strand synthesis step during AAV replication (Fig. 5). The development of self-complementary AAV (scAAV) vectors relies on the packaging of an inverted repeat genome that can fold into dsDNA without the requirement for DNA synthesis or basepairing between multiple vector genomes, thereby bypassing the rate-limiting second-strand DNA synthesis [195]. The scAAV vectors displayed enhanced transduction in comparison with conventional AAV vectors in some tissues and cancer cells but their efficiency still depends on tissue, cell type, and route of administration [196, 197].

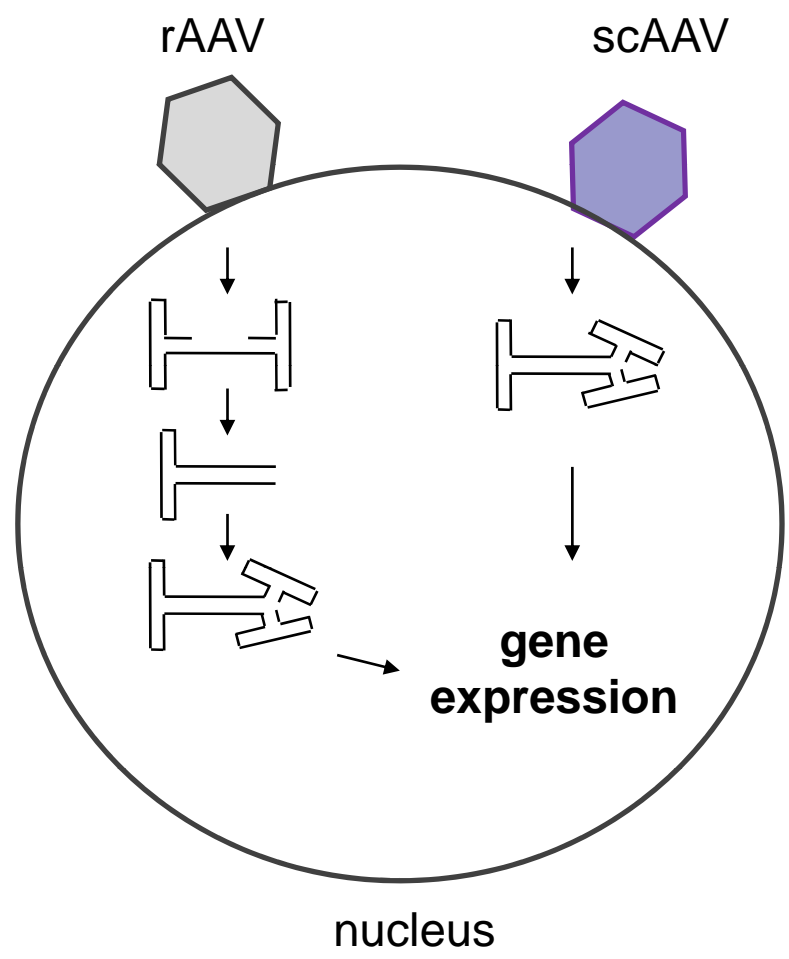

Fig. (5). Comparison between self-complementary AAV (scAAV) and rAAV vectors. scAAV delivers a dimeric inverted repeated DNA molecule thereby bypassing the rate-limiting secondstrand DNA synthesis of rAAV.

Modifications on purification protocols using chromatography techniques have also contributed to increased yields of rAAV and to considerable elimination of contaminating infectious helper viruses [198-201].

\section{HSV/AAV HYBRID VECTORS}

\section{Rationale on the Construction of Hybrid Vectors}

Hybrid gene transfer vectors are designed to combine advantageous properties of different viruses to enhance efficiency of transgene delivery, vector stability and longterm transgene expression, while maintaining high safety standards $[133,202]$. For example, the instability of HSV-1 amplicon vector delivered transgene DNA and transient transgene expression can be overcome by introducing genetic elements that allow the amplicon DNA to be maintained as an episome or to integrate into the host cell genome [203]. The maintenance of the DNA as a replicating episome with chromosome-segregating capability can be achieved by using oriP and the EBNA-1 gene from EpsteinBarr virus (EBV) [204]. Alternatively, viral elements such as AAV ITR and rep [91, 178], or retrovirus components [205] can be used to allow HSV-1 amplicon vector delivered transgenes to integrate into the cell genome. HSV-1 based hybrid vectors have also been constructed to facilitate the production of rAAV vectors.

\section{Hybrid Vectors for the Production of rAAV Vectors}

The efficiency of rAAV production for routine clinical use is a major concern, as most of the systems used for rAAV production rely on transfection protocols, thereby limiting scale-up procedures [206-209]. Replication defective rHSV-1 vectors lacking specific genes (e.g. ICP4, ICP27), which have been developed in order to reduce pathogenicity and cytotoxic effects in vector infected cells, can also be used as helper viruses for the production of rAAV vectors. Specifically, the ability of rHSV-1 that lack the ICP27 gene to efficiently act as a helper virus for rAAV production has been demonstrated [210] ; rAAV production in the absence of ICP27 appeared to be even enhanced. This may be due to the role of ICP27 in regulating transcription and translation of viral and cellular genes, for instance in the inhibition of splicing of host and AAV transcripts, which reduces synthesis of Rep and Cap proteins. The use of replication defective rHSV-1 to deliver AAV rep and cap has also been explored and is a very promising approach as it generates higher yields of rAAV with no detectable helpervirus contamination. Moreover, when allied to infection of a cell line that provides the rAAV template to be packaged, transfection steps can be avoided entirely for the production of rAAV [161, 211]. A protocol with a single infection step can also be accomplished by inserting an AAV ITR-flanked transgene (rAAV genome) cassette into the genome of the rHSV-1 helpervirus [210].

\section{HSV/AAV Hybrid Vectors for Site-Specific Integration into AAVS1}

Over the past 2 decades, the development of improved HSV-1 amplicon packaging systems, in particular the development of helper virus-free packaging systems, has greatly reduced toxicity and immunogenicity, but has had little effect on the stability of amplicon-mediated transgene expression [81, 212-214]. On the other hand, classical rAAV vectors have a small transgene capacity $(\sim 4.6 \mathrm{~kb})$ and, due to the replacement of the rep and cap genes by transgenic sequences, do not conserve the potential of the parent virus for site-specific integration. 
HSV/AAV hybrid amplicon vectors have been developed to overcome these limitations. In addition to the standard HSV-1 amplicon elements, HSV/AAV hybrid vectors incorporate the AAV rep gene and a transgene cassette that is flanked by AAV ITRs (Fig. 2C). By placing the rep gene outside of the ITR cassette, it is not expected to integrate into the host genome. Loss of rep after integration of the ITR cassette eliminates a potential source of toxicity and the risk of rescue/excision of integrated ITR cassettes if the cell is infected by a helpervirus. Because HSV/AAV hybrid vectors can be packaged into HSV-1 virions, they conserve the high efficiency of gene transfer, the large transgene capacity, and the availability of helper virus-free packaging systems. However, after delivery into the host cell nucleus, the vector has the potential to act like AAV with rep-mediated sitespecific integration of the ITR-flanked transgene cassette into the AAVS1 sequence of human chromosome 19 [91].

The initial study on HSV/AAV hybrid vectors demonstrated that these vectors can be packaged into HSV-1 virions by using either helper virus-dependent or helper virus-free packaging systems [81, 215]. Hybrid vectors supported transgene retention and expression significantly longer than standard amplicons [215]. Although the possibility of transgene integration had not been specifically addressed in that study, the percentage of cells expressing the transgene was consistently higher with hybrid vectors that contained the rep gene than with those without rep, or with standard amplicons.

Two other studies have specifically addressed the question whether HSV/AAV hybrid vectors mediate genomic integration, both randomly or site-specifically at the AAVS1 site on human chromosome 19 [91, 178]. Heister and colleagues constructed HSV/AAV hybrid vectors that contained enhanced green fluorescent protein (EGFP) reporter gene flanked by the AAV ITRs and AAV rep. Replication assays demonstrated that both the AAV elements and the HSV-1 elements were functional in the context of the hybrid vector, as shown by the presence of replication intermediates of the ITR-flanked transgene cassette and high molecular-weight concatemeric products of replication from the HSV-1 origin of DNA replication. Such hybrid vectors could be packaged into HSV-1 virions, although the rep sequences incurred a drastic (20 to 2,000-fold) reduction in titers. Site-specific integration at AAVS1 was directly demonstrated by PCR and sequence analysis of ITR-AAVS1 junctions in transduced human 293 cells. The junctions were similar to those that had been identified in cells infected with wt AAV [133, 134, 138, 139, 216-218]. Similar results were obtained by Wang and colleagues who have used also 293 cells and extended the study to other cell lines, including glioma cells (gli36) and primary myoblasts [178]. These investigators used HSV/AAV hybrid vectors that contained rep68 and rep 78 , or no rep, and an ITR-flanked transgene cassette that consisted of an EGFP reporter gene and a neomycin resistance gene. In order to overcome the low-titer packaging problem inherent to the rep gene, they worked on position/orientation effects and found that a decent amplicon vector titer is achieved when the rep genes are placed downstream of the ITR cassette in the forward orientation. Rep mediated a significantly improved efficiency of stable tranduction in all human cells tested, including 293 cells, glioma cells and primary myoblasts. Although neomycin selection was employed for cell cloning, a high proportion of the stably transduced cells had the transgene sequences correctly integrated at the AAVS1 site. In summary, inserting the AAV ITRs and rep genes into an HSV-1 amplicon considerably improved the frequency of stable transgene expression in various proliferating human cell types. Integration events of 4-5 kb ITR-flanked transgene cassettes occurred at a rate of approximately $10-30 \%$ of the HSV/AAV hybrid vector infected cells, and about $50 \%$ of those events occurred specifically at the AAVS1 locus [91, 178]. The potential for AAVS1-specific integration and expression of an entire gene under control of its endogenous promoter using the HSV/AAV vector has also been evaluated. Large functional inserts (approximately $100 \mathrm{~kb}$ ) could be integrated at the AAVS1 site but with a reduced efficiency $[219,220]$.

While the expression of rep $78 / 68$ has been demonstrated to be essential for the ability of HSV/AAV hybrid vectors to mediate site-specific integration, Rep proteins have a strong inhibitory effect on the HSV-1 replication machinery [91, $132,178,221]$. As a consequence, the titers of HSV/AAV hybrid vectors are up to 2000-fold lower than those of standard amplicon vectors [91]. This could be due to (i) the toxicity of Rep, resulting in compromised cell metabolism [222], (ii) the ability of Rep to inhibit HSV-1 replication $[131,132]$, or (iii) the excision of ITR-flanked sequences from the amplicon DNA during packaging.

Potential improvements of the HSV/AAV amplicon vectors may rely on the appropriate use of the $\mathrm{p} 5$ promoter sequence. Indeed, the $\mathrm{p} 5$ promoter driving the expression of rep 78/68 in the afore described HSV/AAV hybrid vectors $[91,178]$ may promote vector-backbone integration [144, 223] owing to its location outside of the therapeutic transgene cassette. In addition, it may also interfere with site-specific integration of the $\mathrm{p} 5$-free ITR-flanked transgenes. Transferring the $\mathrm{p} 5$ promoter sequence from the rep expression cassette to the transgene cassette may not only solve the problem of inadvertent integration of vector backbone sequences but also increase the efficiency of sitespecific integration of the ITR cassette [144, 223].

Liu et al. developed a strategy to overcome the negative effect of AAV Rep on hybrid vector replication and packaging [224]. These investigators designed an HSV/AAV hybrid vector in such a way that little or no rep was expressed during packaging. However, rep was expressed in transduced cells if Cre-recombinase was provided; following site-specific integration, rep was suppressed again. These vectors mediated stable expression in $22 \%$ of transduced Cre-expressing 293 cells. Of those cells, approximately $70 \%$ transduction efficiency was achieved by Rep-mediated sitespecific integration.

The finding that concatameric plasmid replication products from the AAV $\mathrm{p} 5$ replication origin can be packaged into HSV-1 virions if HSV-1 pac is included on the plasmid [108] could lead to the construction of a novel generation of HSV/AAV hybrid amplicon vectors which replicate from a heterologous origin of DNA replication. Such a vector system would have several advantages: first, as described by Philpott and coworkers, the AAV p5 element can efficiently mediate site-specific vector integration into AAVS1 on human chromosome 19 and support long term 
transgene expression $[144,225]$. Second, the AAV p5 replication origin is not inhibited by rep expression, but instead depends on the presence of AAV Rep protein in the replication/packaging process $[108,116,117]$.

The HSV-1 virion contains three proteinaceous compartments for delivery - envelope, tegument, and capsid - which could all be used to deliver functional foreign proteins by fusion with virion components [226]. For example, AAV Rep could be fused with VP16, an abundant HSV-1 tegument protein that enters the cell nucleus along with the virus genome. This would allow eliminating the rep gene from the HSV/AAV hybrid vector genome, as Rep protein could enter the cell nucleus as a fusion with VP16 and there may mediate efficient site-specific integration of the transgene sequences via $\mathrm{p} 5$ or ITRs.

The full potential of HSV/AAV hybrid vectors still needs to be evaluated for site-specific integration in vivo, for example in transgenic mice that carry the human-specific AAVS1 genomic element [227]. As murine [228] and simian [229] AAVS1 orthologs have been found, AAV2 likely can mediate site-specific integration in other species as well.

Future perspective and clinical use of HSV/AAV hybrid vectors are closely linked to standard HSV-1 amplicon vectors as both vector systems depend on the same packaging procedure. Helper virus-free packaging systems require transient transfection of vector DNA and packagingdefective HSV-1 helper DNA, which limits scale up potential. The use of amplicon vectors for clinical trials depends, therefore, on the design of novel packaging procedures that allow the production of large amounts of vector stocks with high titers. Strategies to overcome the adverse effects of the AAV rep gene on the titers of HSV/AAV hybrid vectors have been discussed above. The presence of the genetic elements from AAV on HSV-1 amplicon vectors should not add additional safety concerns to the amplicon system, as AAV is not known to be pathogenic in humans and AAV vectors are already being used in clinical trials.

\section{OTHER HYBRID AMPLICON VECTORS}

\section{HSV/EBV Hybrid Vectors}

Epstein-Barr virus, a human Gammaherpesvirus, has also been used as a hybrid partner with HSV-1 amplicons, due to its potential to persist as an extrachromosomal element in Blymphocytes [230]. The EBV nuclear antigen (EBNA-1) and the origin of DNA replication (oriP) are the sole elements necessary for the long-term episomal retention and are therefore incorporated into the HSV-1 amplicon backbone to support replication and mitotic segregation of the amplicon concatenate in the host cell nucleus [231, 232] (Fig. 2D). HSV/EBV hybrid amplicon vectors have been demonstrated to efficiently transduce various human cells in culture and to support retention of vector sequences in dividing human cells [205]. Stable expression from large transgenes has also been demonstrated [233, 234]. Maintenance of transgene DNA in an episomal state as opposed to genomic integration reduces adverse effects in the host cell. However, long-term expression by these vectors depends on selective pressure and expression of EBNA-1 [95, 235]. In order to circumvent the potential immunogenic and oncogenic properties of EBNA-1 [236], the use of a human episomal retention element (scaffold/matrix attachment region (S/MAR) from the human $\beta$-interferon gene to generate a novel HSV-1 amplicon-based episomal vector has shown great potential even in the absence of selection pressure [93].

\section{HSV/RV Hybrid Vectors}

Elements from retroviruses (RV) have been combined with HSV-1 amplicons in order to achieve prolonged transduction of transgenes. Retroviruses, such as Moloney murine leukaemia virus (MoMLV), integrate randomly into the genome of dividing cells, and produce viral progeny without killing the host cell [237]. Due to the low efficiency of gene transfer, MoMLV -based vectors have been mostly used for ex vivo gene therapy protocols [238, 239]. Although this strategy has shown some therapeutic success in experimental brain tumors $[240,241]$ it is not effective when used in human trials [242-245]. HSV/RV hybrid amplicon vectors containing genetic elements from MoMLV have been developed in order to transduce genes required for the de novo synthesis of small defective retrovirus vectors. These hybrid vectors contain the long terminal repeat sequences (LTRs) flanking a transgene cassette, and the gag, pol, and env genes in a separate cassette (Fig. 2E). The LTRs and $p s i$ sequence comprise the signals necessary for packaging of virion RNA, reverse transcription, and integration into host cell genome. HSV/MoMLV hybrid vectors have indeed been demonstrated to support the packaging of genomic retrovirus RNA expressed from the amplicon vector into MoMLV particles and accomplish integration and transgenic expression in infected naïve cells [246]. One point of caution, however, is the danger of endogenous retroviruses complementing retroviral elements in hybrid vectors. The possibility that endogenous integrases can act on LTRs in hybrid amplicon vectors has indeed been demonstrated [247]. In order to enhance the transduction efficiency of a therapeutic gene in vivo and increase its expression stability, hybrid vectors containing elements from more than 2 viruses have been developed as well. These tribid vectors are based on HSV-1 amplicon vectors and contain elements from MoMLV and either EBV or AAV [205, 248].

\section{REFERENCES}

[1] Davison MD, Rixon FJ, Davison AJ. Identification of genes encoding two capsid proteins (VP24 and VP26) of herpes simplex virus type 1. J Gen Virol 1992; 73 (Pt 10): 2709-13.

[2] Beard PM, Taus NS, Baines JD. DNA cleavage and packaging proteins encoded by genes $\mathrm{U}(\mathrm{L}) 28, \mathrm{U}(\mathrm{L}) 15$, and $\mathrm{U}(\mathrm{L}) 33$ of herpes simplex virus type 1 form a complex in infected cells. J Virol 2002; 76: 4785-91.

[3] Jacobson JG, Yang K, Baines JD, Homa FL. Linker insertion mutations in the herpes simplex virus type 1 UL28 gene: effects on UL28 interaction with UL15 and UL33 and identification of a second-site mutation in the UL15 gene that suppresses a lethal UL28 mutation. J Virol 2006; 80: 12312-23.

[4] Newcomb WW, Homa FL, Brown JC. Herpes simplex virus capsid structure: DNA packaging protein UL25 is located on the external surface of the capsid near the vertices. J Virol 2006; 80: 6286-94.

[5] Thurlow JK, Murphy M, Stow ND, Preston VG. Herpes simplex virus type 1 DNA-packaging protein UL17 is required for efficient binding of UL25 to capsids. J Virol 2006; 80: 2118-26.

[6] Trus BL, Newcomb WW, Cheng N, et al. Allosteric signaling and a nuclear exit strategy: binding of UL25/UL17 heterodimers to DNA-Filled HSV-1 capsids. Mol Cell 2007; 26: 479-89. 
[7] Copeland AM, Newcomb WW, Brown JC. Herpes simplex virus replication: roles of viral proteins and nucleoporins in capsidnucleus attachment. J Virol 2009; 83: 1660-8.

[8] Jovasevic V, Liang L, Roizman B. Proteolytic cleavage of VP1-2 is required for release of herpes simplex virus 1 DNA into the nucleus. J Virol 2008; 82: 3311-9.

[9] Amici C, Rossi A, Costanzo A, et al. Herpes simplex virus disrupts NF-kappaB regulation by blocking its recruitment on the IkappaBalpha promoter and directing the factor on viral genes. J Biol Chem 2006; 281: 7110-7.

[10] Barzilai A, Zivony-Elbom I, Sarid R, Noah E, Frenkel N. The herpes simplex virus type 1 vhs-UL41 gene secures viral replication by temporarily evading apoptotic cellular response to infection: Vhs-UL41 activity might require interactions with elements of cellular mRNA degradation machinery. J Virol 2006; 80: 505-13.

[11] Duffy C, Mbong EF, Baines JD. VP22 of herpes simplex virus 1 promotes protein synthesis at late times in infection and accumulation of a subset of viral mRNAs at early times in infection. $J$ Virol 2009; 83: 1009-17.

[12] Kwong AD, Kruper JA, Frenkel N. Herpes simplex virus virion host shutoff function. J Virol 1988; 62: 912-21.

[13] Liu X, Fitzgerald K, Kurt-Jones E, Finberg R, Knipe DM. Herpesvirus tegument protein activates NF-kappaB signaling through the TRAF6 adaptor protein. Proc Natl Acad Sci USA 2008; 105: 11335-9

[14] Strom T, Frenkel N. Effects of herpes simplex virus on mRNA stability. J Virol 1987; 61: 2198-207.

[15] Campadelli-Fiume G, Amasio M, Avitabile E, et al. The multipartite system that mediates entry of herpes simplex virus into the cell. Rev Med Virol 2007; 17: 313-26.

[16] Polcicova K, Goldsmith K, Rainish BL, Wisner TW, Johnson DC. The extracellular domain of herpes simplex virus $\mathrm{gE}$ is indispensable for efficient cell-to-cell spread: evidence for $\mathrm{gE} / \mathrm{gI}$ receptors. J Virol 2005; 79: 11990-2001.

[17] Campadelli-Fiume G, Qi S, Avitabile E, Foa-Tomasi L, Brandimarti R, Roizman B. Glycoprotein D of herpes simplex virus encodes a domain which precludes penetration of cells expressing the glycoprotein by superinfecting herpes simplex virus. J Virol 1990; 64: 6070-9.

[18] Desai PJ, Schaffer PA, Minson AC. Excretion of non-infectious virus particles lacking glycoprotein $\mathrm{H}$ by a temperature-sensitive mutant of herpes simplex virus type 1 : evidence that $\mathrm{gH}$ is essential for virion infectivity. J Gen Virol 1988; 69 (Pt 6): 1147-56.

[19] Shukla D, Spear PG. Herpesviruses and heparan sulfate: an intimate relationship in aid of viral entry. J Clin Invest 2001; 108: 503-10.

[20] Spear PG, Eisenberg RJ, Cohen GH. Three classes of cell surface receptors for alphaherpesvirus entry. Virology 2000; 275: 1-8.

[21] Favoreel HW. The why's of Y-based motifs in alphaherpesvirus envelope proteins. Virus Res 2006; 117: 202-8.

[22] Nicola AV, McEvoy AM, Straus SE. Roles for endocytosis and low $\mathrm{pH}$ in herpes simplex virus entry into HeLa and Chinese hamster ovary cells. J Virol 2003; 77: 5324-32.

[23] Clement C, Tiwari V, Scanlan PM, Valyi-Nagy T, Yue BY, Shukla D. A novel role for phagocytosis-like uptake in herpes simplex virus entry. J Cell Biol 2006; 174: 1009-21.

[24] Dohner K, Radtke K, Schmidt S, Sodeik B. Eclipse phase of herpes simplex virus type 1 infection: Efficient dynein-mediated capsid transport without the small capsid protein VP26. J Virol 2006; 80: 8211-24.

[25] Dohner K, Wolfstein A, Prank U, et al. Function of dynein and dynactin in herpes simplex virus capsid transport. Mol Biol Cell 2002; 13: 2795-809.

[26] Sodeik B, Ebersold MW, Helenius A. Microtubule-mediated transport of incoming herpes simplex virus 1 capsids to the nucleus. J Cell Biol 1997; 136: 1007-21.

[27] Ojala PM, Sodeik B, Ebersold MW, Kutay U, Helenius A. Herpes simplex virus type 1 entry into host cells: reconstitution of capsid binding and uncoating at the nuclear pore complex in vitro. $\mathrm{Mol}$ Cell Biol 2000; 20: 4922-31.

[28] Shahin V, Hafezi W, Oberleithner H, et al. The genome of HSV-1 translocates through the nuclear pore as a condensed rod-like structure. J Cell Sci 2006; 119: 23-30.

[29] Lockshon D, Galloway DA. Cloning and characterization of oriL2, a large palindromic DNA replication origin of herpes simplex virus type 2. J Virol 1986; 58: 513-21.
[30] Stow ND. Localization of an origin of DNA replication within the TRS/IRS repeated region of the herpes simplex virus type 1 genome. EMBO J 1982; 1: 863-7.

[31] Roizman B, Sears AE. Herpes simplex viruses and their replication. New York, N.Y.: Raven Press, Ltd; 1996.

[32] Garber DA, Beverley SM, Coen DM. Demonstration of circularization of herpes simplex virus DNA following infection using pulsed field gel electrophoresis. Virology 1993; 197: 459-62.

[33] Jackson SA, DeLuca NA. Relationship of herpes simplex virus genome configuration to productive and persistent infections. Proc Natl Acad Sci USA 2003; 100: 7871-6.

[34] Ben-Porat T, Tokazewski SA. Replication of herpesvirus DNA. II Sedimentation characteristics of newly synthesized DNA. Virology 1977; 79: 292-301.

[35] Jacob RJ, Morse LS, Roizman B. Anatomy of herpes simplex virus DNA. XII. Accumulation of head-to-tail concatemers in nuclei of infected cells and their role in the generation of the four isomeric arrangements of viral DNA. J Virol 1979; 29: 448-57.

[36] Jacob RJ, Roizman B. Anatomy of herpes simplex virus DNA VIII. Properties of the replicating DNA. J Virol 1977; 23: 394-411.

[37] Deiss LP, Frenkel N. Herpes simplex virus amplicon: cleavage of concatemeric DNA is linked to packaging and involves amplification of the terminally reiterated a sequence. J Virol 1986; 57: 933-41

[38] Roizman B. The function of herpes simplex virus genes: a primer for genetic engineering of novel vectors. Proc Natl Acad Sci USA 1996; 93: 11307-12.

[39] Conley AJ, Knipe DM, Jones PC, Roizman B. Molecular genetics of herpes simplex virus. VII. Characterization of a temperaturesensitive mutant produced by in vitro mutagenesis and defective in DNA synthesis and accumulation of gamma polypeptides. J Virol 1981; 37: 191-206.

[40] Honess RW, Roizman B. Regulation of herpesvirus macromolecular synthesis. I. Cascade regulation of the synthesis of three groups of viral proteins. J Virol 1974; 14: 8-19.

[41] Browne H, Bell S, Minson T, Wilson DW. An endoplasmic reticulum-retained herpes simplex virus glycoprotein $\mathrm{H}$ is absent from secreted virions: evidence for reenvelopment during egress. J Virol 1996; 70: 4311-6.

[42] Skepper JN, Whiteley A, Browne H, Minson A. Herpes simplex virus nucleocapsids mature to progeny virions by an envelopment -> deenvelopment --> reenvelopment pathway. J Virol 2001; 75: 5697-702.

[43] Beitia Ortiz de Zarate I, Kaelin K, Rozenberg F. Effects of mutations in the cytoplasmic domain of herpes simplex virus type 1 glycoprotein $\mathrm{B}$ on intracellular transport and infectivity. J Virol 2004; 78: 1540-51.

[44] Harley CA, Dasgupta A, Wilson DW. Characterization of herpes simplex virus-containing organelles by subcellular fractionation: role for organelle acidification in assembly of infectious particles. J Virol 2001; 75: 1236-51

[45] Johnson DC, Webb M, Wisner TW, Brunetti C. Herpes simplex virus $\mathrm{gE} / \mathrm{gI}$ sorts nascent virions to epithelial cell junctions, promoting virus spread. J Virol 2001; 75: 821-33.

[46] McMillan TN, Johnson DC. Cytoplasmic domain of herpes simplex virus $\mathrm{gE}$ causes accumulation in the trans-Golgi network, a site of virus envelopment and sorting of virions to cell junctions. J Virol 2001; 75: 1928-40

[47] Mettenleiter TC, Klupp BG, Granzow H. Herpesvirus assembly: an update. Virus Res 2009; 143: 222-34.

[48] Turcotte S, Letellier J, Lippe R. Herpes simplex virus type capsids transit by the trans-Golgi network, where viral glycoproteins accumulate independently of capsid egress. J Virol 2005; 79: 8847-60.

[49] Whiteley A, Bruun B, Minson T, Browne H. Effects of targeting herpes simplex virus type $1 \mathrm{gD}$ to the endoplasmic reticulum and trans-Golgi network. J Virol 1999; 73: 9515-20.

[50] Leuzinger H, Ziegler U, Schraner EM, et al. Herpes simplex virus 1 envelopment follows two diverse pathways. J Virol 2005; 79: 13047-59.

[51] Wild P, Engels M, Senn C, et al. Impairment of nuclear pores in bovine herpesvirus 1-infected MDBK cells. J Virol 2005; 79: 1071 83.

[52] Wild P, Schraner EM, Cantieni D, et al. The significance of the Golgi complex in envelopment of bovine herpesvirus 1 (BHV-1) as 
revealed by cryobased electron microscopy. Micron 2002; 33: 32737.

[53] Avitabile E, Di Gaeta S, Torrisi MR, Ward PL, Roizman B, Campadelli-Fiume G. Redistribution of microtubules and Golgi apparatus in herpes simplex virus-infected cells and their role in viral exocytosis. J Virol 1995; 69: 7472-82.

[54] Brunetti CR, Dingwell KS, Wale C, Graham FL, Johnson DC. Herpes simplex virus $\mathrm{gD}$ and virions accumulate in endosomes by mannose 6-phosphate-dependent and -independent mechanisms. J Virol 1998; 72: 3330-9.

[55] Whealy ME, Card JP, Meade RP, Robbins AK, Enquist LW. Effect of brefeldin A on alphaherpesvirus membrane protein glycosylation and virus egress. J Virol 1991; 65: 1066-81.

[56] Steiner I, Spivack JG, Deshmane SL, Ace CI, Preston CM, Fraser NW. A herpes simplex virus type 1 mutant containing a nontransinducing Vmw65 protein establishes latent infection in vivo in the absence of viral replication and reactivates efficiently from explanted trigeminal ganglia. J Virol 1990; 64: 1630-8.

[57] Preston CM. Repression of viral transcription during herpes simplex virus latency. J Gen Virol 2000; 81: 1-19.

[58] Thompson RL, Sawtell NM. The herpes simplex virus type 1 latency-associated transcript gene regulates the establishment of latency. J Virol 1997; 71: 5432-40.

[59] Bloom DC, Hill JM, Devi-Rao G, Wagner EK, Feldman LT, Stevens JG. A 348-base-pair region in the latency-associated transcript facilitates herpes simplex virus type 1 reactivation. J Virol 1996; 70: 2449-59.

[60] Hill JM, Garza HH, Jr., Su YH, et al. A 437-base-pair deletion at the beginning of the latency-associated transcript promoter significantly reduced adrenergically induced herpes simplex virus type 1 ocular reactivation in latently infected rabbits. J Virol 1997; 71: 6555-9.

[61] Bartel DP. MicroRNAs: genomics, biogenesis, mechanism, and function. Cell 2004; 116: 281-97.

[62] Murphy E, Vanicek J, Robins H, Shenk T, Levine AJ. Suppression of immediate-early viral gene expression by herpesvirus-coded microRNAs: implications for latency. Proc Natl Acad Sci USA 2008; 105: 5453-8.

[63] Randall G, Roizman B. Transcription of the derepressed open reading frame $\mathrm{P}$ of herpes simplex virus 1 precludes the expression of the antisense gamma(1)34.5 gene and may account for the attenuation of the mutant virus. J Virol 1997; 71: 7750-7.

[64] Umbach JL, Kramer MF, Jurak I, Karnowski HW, Coen DM, Cullen BR. MicroRNAs expressed by herpes simplex virus 1 during latent infection regulate viral mRNAs. Nature 2008; 454: 780-3.

[65] Yeh L, Schaffer PA. A novel class of transcripts expressed with late kinetics in the absence of ICP4 spans the junction between the long and short segments of the herpes simplex virus type 1 genome. J Virol 1993; 67: 7373-82.

[66] Amelio AL, McAnany PK, Bloom DC. A chromatin insulator-like element in the herpes simplex virus type 1 latency-associated transcript region binds CCCTC-binding factor and displays enhancer-blocking and silencing activities. J Virol 2006; 80: 235868.

[67] Jordan R, Schaffer PA. Activation of gene expression by herpes simplex virus type 1 ICP0 occurs at the level of mRNA synthesis. J Virol 1997; 71: 6850-62.

[68] Pesola JM, Zhu J, Knipe DM, Coen DM. Herpes simplex virus 1 immediate-early and early gene expression during reactivation from latency under conditions that prevent infectious virus production. J Virol 2005; 79: 14516-25.

[69] Sawtell NM, Thompson RL, Haas RL. Herpes simplex virus DNA synthesis is not a decisive regulatory event in the initiation of lytic viral protein expression in neurons in vivo during primary infection or reactivation from latency. J Virol 2006; 80: 38-50.

[70] Thompson RL, Sawtell NM. Evidence that the herpes simplex virus type 1 ICP0 protein does not initiate reactivation from latency in vivo. J Virol 2006; 80: 10919-30.

[71] Thompson RL, Preston CM, Sawtell NM. De novo synthesis of VP16 coordinates the exit from HSV latency in vivo. PLoS Pathog 2009; 5: e1000352.

[72] Krisky DM, Marconi PC, Oligino T, Rouse RJ, Fink DJ, Glorioso JC. Rapid method for construction of recombinant HSV gene transfer vectors. Gene Ther 1997; 4: 1120-5.
[73] Cuchet D, Potel C, Thomas J, Epstein AL. HSV-1 amplicon vectors: a promising and versatile tool for gene delivery. Expert Opin Biol Ther 2007; 7: 975-95.

[74] Spaete RR, Frenkel N. The herpes simplex virus amplicon: a new eucaryotic defective-virus cloning-amplifying vector. Cell 1982; 30: 295-304.

[75] Spaete RR, Frenkel N. The herpes simplex virus amplicon: analyses of cis-acting replication functions. Proc Natl Acad Sci USA 1985; 82: 694-8.

[76] Kwong AD, Frenkel N. Biology of herpes symplex virus (HSV) defective viruses and development of the amplicon system. New York: Academic Press; 1998.

[77] Lu B, Federoff HJ, Wang Y, Goldsmith LA, Scott G. Topical application of viral vectors for epidermal gene transfer. J Invest Dermatol 1997; 108: 803-8.

[78] Willis RA, Bowers WJ, Turner MJ, et al. Dendritic cells transduced with HSV-1 amplicons expressing prostate-specific antigen generate antitumor immunity in mice. Hum Gene Ther 2001; 12: 1867-79.

[79] Bowers WJ, Chen X, Guo H, Frisina DR, Federoff HJ, Frisina RD. Neurotrophin-3 transduction attenuates cisplatin spiral ganglion neuron ototoxicity in the cochlea. Mol Ther 2002; 6: 12-8.

[80] Derby ML, Sena-Esteves M, Breakefield XO, Corey DP. Gene transfer into the mammalian inner ear using HSV-1 and vaccinia virus vectors. Hear Res 1999; 134: 1-8.

[81] Fraefel C, Jacoby DR, Lage C, et al. Gene transfer into hepatocytes mediated by helper virus-free HSV/AAV hybrid vectors. Mol Med 1997; 3: 813-25.

[82] Wang Y, Mukherjee S, Fraefel C, Breakefield XO, Allen PD. Herpes simplex virus type 1 amplicon vector-mediated gene transfer to muscle. Hum Gene Ther 2002; 13: 261-73.

[83] Neve RL, Neve KA, Nestler EJ, Carlezon WA, Jr. Use of herpes virus amplicon vectors to study brain disorders. Biotechniques 2005; 39: 381-91.

[84] Saydam O, Glauser DL, Heid I, et al. Herpes simplex virus 1 amplicon vector-mediated siRNA targeting epidermal growth factor receptor inhibits growth of human glioma cells in vivo. Mol Ther 2005; 12: 803-12.

[85] Saydam O, Saydam N, Glauser DL, et al. HSV-1 ampliconmediated post-transcriptional inhibition of Rad51 sensitizes human glioma cells to ionizing radiation. Gene Ther 2007; 14: 1143-51.

[86] Shah $\mathrm{K}$, Tung $\mathrm{CH}$, Chang $\mathrm{CH}$, et al. In vivo imaging of HIV protease activity in amplicon vector-transduced gliomas. Cancer Res 2004; 64: 273-8

[87] Suzuki M, Kasai K, Saeki Y. Plasmid DNA sequences present in conventional herpes simplex virus amplicon vectors cause rapid transgene silencing by forming inactive chromatin. J Virol 2006; 80: 3293-300.

[88] Kaplitt MG, Kwong AD, Kleopoulos SP, Mobbs CV, Rabkin SD, Pfaff DW. Preproenkephalin promoter yields region-specific and long-term expression in adult brain after direct in vivo gene transfer via a defective herpes simplex viral vector. Proc Natl Acad Sci USA 1994; 91: 8979-83.

[89] Song S, Wang Y, Bak SY, et al. An HSV-1 vector containing the rat tyrosine hydroxylase promoter enhances both long-term and cell type-specific expression in the midbrain. J Neurochem 1997; 68: 1792-803.

[90] Bowers WJ, Mastrangelo MA, Howard DF, Southerland HA, Maguire-Zeiss KA, Federoff HJ. Neuronal precursor-restricted transduction via in utero CNS gene delivery of a novel bipartite HSV amplicon/transposase hybrid vector. Mol Ther 2006; 13: 5808.

[91] Heister T, Heid I, Ackermann M, Fraefel C. Herpes simplex virus type 1/adeno-associated virus hybrid vectors mediate site-specific integration at the adeno-associated virus preintegration site, AAVS1, on human chromosome 19. J Virol 2002; 76: 7163-73.

[92] Lufino MM, Edser PA, Wade-Martins R. Advances in highcapacity extrachromosomal vector technology: episomal maintenance, vector delivery, and transgene expression. Mol Ther 2008; 16: 1525-38.

[93] Lufino MM, Manservigi R, Wade-Martins R. An S/MAR-based infectious episomal genomic DNA expression vector provides long-term regulated functional complementation of LDLR deficiency. Nucleic Acids Res 2007; 35: e98. 
[94] Moralli D, Simpson KM, Wade-Martins R, Monaco ZL. A novel human artificial chromosome gene expression system using herpes simplex virus type 1 vectors. EMBO Rep 2006; 7: 911-8.

[95] Muller L, Saydam O, Saeki Y, Heid I, Fraefel C. Gene transfer into hepatocytes mediated by herpes simplex virus-Epstein-Barr virus hybrid amplicons. J Virol Methods 2005; 123: 65-72.

[96] Berns KI, Giraud C. Biology of adeno-associated virus. Curr Top Microbiol Immunol 1996; 218: 1-23.

[97] Bantel-Schaal U, zur Hausen H. Characterization of the DNA of a defective human parvovirus isolated from a genital site. Virology 1984; 134: 52-63.

[98] Erles K, Sebokova P, Schlehofer JR. Update on the prevalence of serum antibodies (IgG and IgM) to adeno-associated virus (AAV). J Med Virol 1999; 59: 406-11.

[99] Parks WP, Boucher DW, Melnick JL, Taber LH, Yow MD. Seroepidemiological and Ecological Studies of the AdenovirusAssociated Satellite Viruses. Infect Immun 1970; 2: 716-22.

[100] Rutledge EA, Halbert CL, Russell DW. Infectious clones and vectors derived from adeno-associated virus (AAV) serotypes other than AAV type 2. J Virol 1998; 72: 309-19.

[101] Xiao W, Chirmule N, Berta SC, McCullough B, Gao G, Wilson JM. Gene therapy vectors based on adeno-associated virus type 1 . J Virol 1999; 73: 3994-4003.

[102] Gao G, Vandenberghe LH, Wilson JM. New recombinant serotypes of AAV vectors. Curr Gene Ther 2005; 5: 285-97.

[103] Halbert CL, Rutledge EA, Allen JM, Russell DW, Miller AD. Repeat transduction in the mouse lung by using adeno-associated virus vectors with different serotypes. J Virol 2000; 74: 1524-32.

[104] Peden CS, Burger C, Muzyczka N, Mandel RJ. Circulating antiwild-type adeno-associated virus type 2 (AAV2) antibodies inhibit recombinant AAV2 (rAAV2)-mediated, but not rAAV5-mediated, gene transfer in the brain. J Virol 2004; 78: 6344-59.

[105] Ni TH, McDonald WF, Zolotukhin I, et al. Cellular proteins required for adeno-associated virus DNA replication in the absence of adenovirus coinfection. J Virol 1998; 72: 2777-87.

[106] Francois A, Guilbaud M, Awedikian R, Chadeuf G, Moullier P, Salvetti A. The cellular TATA binding protein is required for repdependent replication of a minimal adeno-associated virus type 2 p5 element. J Virol 2005; 79: 11082-94

[107] Pereira DJ, McCarty DM, Muzyczka N. The adeno-associated virus (AAV) Rep protein acts as both a repressor and an activator to regulate AAV transcription during a productive infection. J Virol 1997; 71: 1079-88.

[108] Glauser DL, Saydam O, Balsiger NA, et al. Four-dimensional visualization of the simultaneous activity of alternative adenoassociated virus replication origins. J Virol 2005; 79: 12218-30.

[109] Kyostio SR, Owens RA, Weitzman MD, Antoni BA, Chejanovsky N, Carter BJ. Analysis of adeno-associated virus (AAV) wild-type and mutant Rep proteins for their abilities to negatively regulate AAV p5 and p19 mRNA levels. J Virol 1994; 68: 2947-57.

[110] Linden RM, Berns KI. Molecular biology of adeno-associated viruses. Contrib Microbiol 2000; 4: 68-84.

[111] McCarty DM, Young SM, Jr., Samulski RJ. Integration of adenoassociated virus (AAV) and recombinant AAV vectors. Annu Rev Genet 2004; 38: 819-45.

[112] Ward P, Berns KI. Minimum origin requirements for linear duplex AAV DNA replication in vitro. Virology 1995; 209: 692-5.

[113] Ward P, Falkenberg M, Elias P, Weitzman M, Linden RM. Repdependent initiation of adeno-associated virus type 2 DNA replication by a herpes simplex virus type 1 replication complex in a reconstituted system. J Virol 2001; 75: 10250-8.

[114] Ward P, Berns KI. In vitro replication of adeno-associated virus DNA: enhancement by extracts from adenovirus-infected HeLa cells. J Virol 1996; 70: 4495-501.

[115] Hong G, Ward P, Berns KI. Intermediates of adeno-associated virus DNA replication in vitro. J Virol 1994; 68: 2011-5.

[116] Musatov S, Roberts J, Pfaff D, Kaplitt M. A cis-acting element that directs circular adeno-associated virus replication and packaging. $\mathrm{J}$ Virol 2002; 76: 12792-802.

[117] Nony P, Tessier J, Chadeuf G, et al. Novel cis-acting replication element in the adeno-associated virus type 2 genome is involved in amplification of integrated rep-cap sequences. J Virol 2001; 75: 9991-4.

[118] Hoggan MD, Blacklow NR, Rowe WP. Studies of small DNA viruses found in various adenovirus preparations: physical, biological, and immunological characteristics. Proc Natl Acad Sci USA 1966; 55: 1467-74.

[119] Buller RM, Janik JE, Sebring ED, Rose JA. Herpes simplex virus types 1 and 2 completely help adenovirus-associated virus replication. J Virol 1981; 40: 241-7.

[120] McPherson RA, Rosenthal LJ, Rose JA. Human cytomegalovirus completely helps adeno-associated virus replication. Virology 1985; 147: 217-22.

[121] Shiau AL, Liu PS, Wu CL. Novel strategy for generation and titration of recombinant adeno-associated virus vectors. J Virol 2005; 79: 193-201.

[122] Schlehofer JR, Ehrbar M, zur Hausen H. Vaccinia virus, herpes simplex virus, and carcinogens induce DNA amplification in a human cell line and support replication of a helpervirus dependent parvovirus. Virology 1986; 152: 110-7.

[123] Grifman M, Chen NN, Gao GP, Cathomen T, Wilson JM, Weitzman MD. Overexpression of cyclin A inhibits augmentation of recombinant adeno-associated virus transduction by the adenovirus E4orf6 protein. J Virol 1999; 73: 10010-9.

[124] Roizman B, Roane PR, Jr. The Multiplication Of Herpes Simplex Virus. Ii. The Relation Between Protein Synthesis And The Duplication Of Viral Dna In Infected Hep-2 Cells. Virology 1964; 22: 262-9.

[125] Taddeo B, Esclatine A, Roizman B. Post-transcriptional processing of cellular RNAs in herpes simplex virus-infected cells. Biochem Soc Trans 2004; 32: 697-701.

[126] Heilbronn R, Engstler M, Weger S, Krahn A, Schetter C, Boshart M. ssDNA-dependent colocalization of adeno-associated virus Rep and herpes simplex virus ICP8 in nuclear replication domains. Nucleic Acids Res 2003; 31: 6206-13.

[127] Slanina H, Weger S, Stow ND, Kuhrs A, Heilbronn R. Role of the herpes simplex virus helicase-primase complex during adenoassociated virus DNA replication. J Virol 2006; 80: 5241-50.

[128] Stracker TH, Cassell GD, Ward P, et al. The Rep protein of adenoassociated virus type 2 interacts with single-stranded DNA-binding proteins that enhance viral replication. J Virol 2004; 78: 441-53.

[129] Weindler FW, Heilbronn R. A subset of herpes simplex virus replication genes provides helper functions for productive adenoassociated virus replication. J Virol 1991; 65: 2476-83.

[130] Alazard-Dany N, Nicolas A, Ploquin A, et al. Definition of herpes simplex virus type 1 helper activities for adeno-associated virus early replication events. PLoS Pathog 2009; 5: e1000340.

[131] Glauser DL, Strasser R, Laimbacher AS, et al. Live covisualization of competing adeno-associated virus and herpes simplex virus type 1 DNA replication: molecular mechanisms of interaction. J Virol 2007; 81: 4732-43.

[132] Heilbronn R, Burkle A, Stephan S, zur Hausen H. The adenoassociated virus rep gene suppresses herpes simplex virus-induced DNA amplification. J Virol 1990; 64: 3012-8.

[133] Kotin RM, Linden RM, Berns KI. Characterization of a preferred site on human chromosome $19 \mathrm{q}$ for integration of adeno-associated virus DNA by non-homologous recombination. EMBO J 1992; 11: 5071-8.

[134] Samulski RJ, Zhu X, Xiao X, et al. Targeted integration of adenoassociated virus (AAV) into human chromosome 19. EMBO J 1991; 10: 3941-50.

[135] Surosky RT, Urabe M, Godwin SG, et al. Adeno-associated virus Rep proteins target DNA sequences to a unique locus in the human genome. J Virol 1997; 71: 7951-9.

[136] Weitzman MD, Kyostio SR, Kotin RM, Owens RA. Adenoassociated virus (AAV) Rep proteins mediate complex formation between AAV DNA and its integration site in human DNA. Proc Natl Acad Sci USA 1994; 91: 5808-12.

[137] Dyall J, Berns KI. Site-specific integration of adeno-associated virus into an episome with the target locus via a deletionsubstitution mechanism. J Virol 1998; 72: 6195-8.

[138] Giraud C, Winocour E, Berns KI. Site-specific integration by adeno-associated virus is directed by a cellular DNA sequence. Proc Natl Acad Sci USA 1994; 91: 10039-43.

[139] Linden RM, Ward P, Giraud C, Winocour E, Berns KI. Sitespecific integration by adeno-associated virus. Proc Natl Acad Sci USA 1996; 93: 11288-94.

[140] Smith RH. Adeno-associated virus integration: virus vs vector. Gene Ther 2008; 15: 817-22. 
[141] Urcelay E, Ward P, Wiener SM, Safer B, Kotin RM. Asymmetric replication in vitro from a human sequence element is dependent on adeno-associated virus Rep protein. J Virol 1995; 69: 2038-46.

[142] Young SM, Jr., McCarty DM, Degtyareva N, Samulski RJ. Roles of adeno-associated virus Rep protein and human chromosome 19 in site-specific recombination. J Virol 2000; 74: 3953-66.

[143] Young SM, Jr., Samulski RJ. Adeno-associated virus (AAV) sitespecific recombination does not require a Rep-dependent origin of replication within the AAV terminal repeat. Proc Natl Acad Sci USA 2001; 98: 13525-30.

[144] Philpott NJ, Gomos J, Berns KI, Falck-Pedersen E. A p5 integration efficiency element mediates Rep-dependent integration into AAVS1 at chromosome 19. Proc Natl Acad Sci USA 2002; 99 : 12381-5.

[145] Feng D, Chen J, Yue Y, Zhu H, Xue J, Jia WW. A 16bp Rep binding element is sufficient for mediating Rep-dependent integration into AAVS1. J Mol Biol 2006; 358: 38-45.

[146] Geoffroy MC, Epstein AL, Toublanc E, Moullier P, Salvetti A. Herpes simplex virus type 1 ICP0 protein mediates activation of adeno-associated virus type 2 rep gene expression from a latent integrated form. J Virol 2004; 78: 10977-86.

[147] Meyers C, Mane M, Kokorina N, Alam S, Hermonat PL. Ubiquitous human adeno-associated virus type 2 autonomously replicates in differentiating keratinocytes of a normal skin model. Virology 2000; 272: 338-46.

[148] Yakobson B, Hrynko TA, Peak MJ, Winocour E. Replication of adeno-associated virus in cells irradiated with UV light at $254 \mathrm{~nm}$. J Virol 1989; 63: 1023-30.

[149] Yalkinoglu AO, Heilbronn R, Burkle A, Schlehofer JR, zur Hausen H. DNA amplification of adeno-associated virus as a response to cellular genotoxic stress. Cancer Res 1988; 48: 3123-9.

[150] Summerford C, Samulski RJ. Membrane-associated heparan sulfate proteoglycan is a receptor for adeno-associated virus type 2 virions. J Virol 1998; 72: 1438-45.

[151] Qing K, Mah C, Hansen J, Zhou S, Dwarki V, Srivastava A. Human fibroblast growth factor receptor 1 is a co-receptor for infection by adeno-associated virus 2. Nat Med 1999; 5: 71-7.

[152] Summerford C, Bartlett JS, Samulski RJ. AlphaVbeta5 integrin: a co-receptor for adeno-associated virus type 2 infection. Nat Med 1999; 5: 78-82.

[153] Bartlett JS, Wilcher R, Samulski RJ. Infectious entry pathway of adeno-associated virus and adeno-associated virus vectors. J Virol 2000; 74: 2777-85.

[154] Ding W, Zhang L, Yan Z, Engelhardt JF. Intracellular trafficking of adeno-associated viral vectors. Gene Ther 2005; 12: 873-80.

[155] Ding W, Zhang LN, Yeaman C, Engelhardt JF. rAAV2 traffics through both the late and the recycling endosomes in a dosedependent fashion. Mol Ther 2006; 13: 671-82.

[156] Lux K, Goerlitz N, Schlemminger S, et al. Green fluorescent protein-tagged adeno-associated virus particles allow the study of cytosolic and nuclear trafficking. J Virol 2005; 79: 11776-87.

[157] Hansen J, Qing K, Srivastava A. Infection of purified nuclei by adeno-associated virus 2. Mol Ther 2001; 4: 289-96.

[158] Daya S, Berns KI. Gene therapy using adeno-associated virus vectors. Clin Microbiol Rev 2008; 21: 583-93.

[159] Kwon I, Schaffer DV. Designer gene delivery vectors: molecular engineering and evolution of adeno-associated viral vectors for enhanced gene transfer. Pharm Res 2008; 25: 489-99.

[160] Park K, Kim WJ, Cho YH, et al. Cancer gene therapy using adenoassociated virus vectors. Front Biosci 2008; 13: 2653-9.

[161] Conway JE, Rhys CM, Zolotukhin I, et al. High-titer recombinant adeno-associated virus production utilizing a recombinant herpes simplex virus type I vector expressing AAV-2 Rep and Cap. Gene Ther 1999; 6: 986-93.

[162] Zhang HG, Wang YM, Xie JF, et al. Recombinant adenovirus expressing adeno-associated virus cap and rep proteins supports production of high-titer recombinant adeno-associated virus. Gene Ther 2001; 8: 704-12.

[163] Grimm D, Kern A, Rittner K, Kleinschmidt JA. Novel tools for production and purification of recombinant adenoassociated virus vectors. Hum Gene Ther 1998; 9: 2745-60.

[164] Clark KR, Voulgaropoulou F, Fraley DM, Johnson PR. Cell lines for the production of recombinant adeno-associated virus. Hum Gene Ther 1995; 6: 1329-41.

[165] Clark KR, Voulgaropoulou F, Johnson PR. A stable cell line carrying adenovirus-inducible rep and cap genes allows for infectivity titration of adeno-associated virus vectors. Gene Ther 1996; 3: 1124-32.

[166] Liu X, Voulgaropoulou F, Chen R, Johnson PR, Clark KR. Selective Rep-Cap gene amplification as a mechanism for high-titer recombinant AAV production from stable cell lines. Mol Ther 2000; 2: 394-403.

[167] Meghrous J, Aucoin MG, Jacob D, Chahal PS, Arcand N, Kamen AA. Production of recombinant adeno-associated viral vectors using a baculovirus/insect cell suspension culture system: from shake flasks to a 20-L bioreactor. Biotechnol Prog 2005; 21: 154 60.

[168] Urabe M, Nakakura T, Xin KQ, et al. Scalable generation of hightiter recombinant adeno-associated virus type 5 in insect cells. J Virol 2006; 80: 1874-85.

[169] Janson C, McPhee S, Bilaniuk L, et al. Clinical protocol. Gene therapy of Canavan disease: AAV-2 vector for neurosurgical delivery of aspartoacylase gene (ASPA) to the human brain. Hum Gene Ther 2002; 13: 1391-412.

[170] Carter BJ. Adeno-associated virus vectors in clinical trials. Hum Gene Ther 2005; 16: 541-50.

[171] Kaplitt MG, Feigin A, Tang C, et al. Safety and tolerability of gene therapy with an adeno-associated virus (AAV) borne GAD gene for Parkinson's disease: an open label, phase I trial. Lancet 2007; 369: 2097-105.

[172] Mandel RJ, Burger C. Clinical trials in neurological disorders using AAV vectors: promises and challenges. Curr Opin Mol Ther 2004; 6: 482-90.

[173] Mandel RJ, Manfredsson FP, Foust KD, et al. Recombinant adenoassociated viral vectors as therapeutic agents to treat neurological disorders. Mol Ther 2006; 13: 463-83.

[174] Tenenbaum L, Chtarto A, Lehtonen E, Velu T, Brotchi J, Levivier M. Recombinant AAV-mediated gene delivery to the central nervous system. J Gene Med 2004; 6(Suppl 1): S212-22.

[175] Burger C, Gorbatyuk OS, Velardo MJ, et al. Recombinant AAV viral vectors pseudotyped with viral capsids from serotypes 1,2 , and 5 display differential efficiency and cell tropism after delivery to different regions of the central nervous system. Mol Ther 2004; 10: 302-17.

[176] Furler S, Paterna JC, Weibel M, Bueler H. Recombinant AAV vectors containing the foot and mouth disease virus $2 \mathrm{~A}$ sequence confer efficient bicistronic gene expression in cultured cells and rat substantia nigra neurons. Gene Ther 2001; 8: 864-73.

[177] Landgraf R, Frank E, Aldag JM, et al. Viral vector-mediated gene transfer of the vole V1a vasopressin receptor in the rat septum: improved social discrimination and active social behaviour. Eur J Neurosci 2003; 18: 403-11.

[178] Wang Y, Camp SM, Niwano M, et al. Herpes simplex virus type 1/adeno-associated virus rep $(+)$ hybrid amplicon vector improves the stability of transgene expression in human cells by site-specific integration. J Virol 2002; 76: 7150-62.

[179] Bartlett JS, Samulski RJ, McCown TJ. Selective and rapid uptake of adeno-associated virus type 2 in brain. Hum Gene Ther 1998; 9: 1181-6.

[180] Klein RL, Meyer EM, Peel AL, et al. Neuron-specific transduction in the rat septohippocampal or nigrostriatal pathway by recombinant adeno-associated virus vectors. Exp Neurol 1998; 150: 183-94.

[181] McCown TJ, Xiao X, Li J, Breese GR, Samulski RJ. Differential and persistent expression patterns of CNS gene transfer by an adeno-associated virus (AAV) vector. Brain Res 1996; 713: 99107.

[182] Xu Y, Gu Y, Wu P, Li GW, Huang LY. Efficiencies of transgene expression in nociceptive neurons through different routes of delivery of adeno-associated viral vectors. Hum Gene Ther 2003; 14: 897-906.

[183] Thorsen F, Afione S, Huszthy PC, et al. Adeno-associated virus (AAV) serotypes 2, 4 and 5 display similar transduction profiles and penetrate solid tumor tissue in models of human glioma. J Gene Med 2006; 8: 1131-40

[184] Davidson BL, Stein CS, Heth JA, et al. Recombinant adenoassociated virus type 2,4 , and 5 vectors: transduction of variant cell types and regions in the mammalian central nervous system. Proc Natl Acad Sci USA 2000; 97: 3428-32.

[185] Wang C, Wang CM, Clark KR, Sferra TJ. Recombinant AAV serotype 1 transduction efficiency and tropism in the murine brain. Gene Ther 2003; 10: 1528-34. 
[186] Burger C, Nash K, Mandel RJ. Recombinant adeno-associated viral vectors in the nervous system. Hum Gene Ther 2005; 16: 781-91.

[187] Lo WD, Qu G, Sferra TJ, Clark R, Chen R, Johnson PR. Adenoassociated virus-mediated gene transfer to the brain: duration and modulation of expression. Hum Gene Ther 1999; 10: 201-13.

[188] Mastakov MY, Baer K, Symes CW, Leichtlein CB, Kotin RM, During MJ. Immunological aspects of recombinant adenoassociated virus delivery to the mammalian brain. J Virol 2002; 76 : 8446-54.

[189] Herzog RW. Immune responses to AAV capsid: are mice not humans after all? Mol Ther 2007; 15: 649-50.

[190] Lowenstein PR, Mandel RJ, Xiong WD, Kroeger K, Castro MG. Immune responses to adenovirus and adeno-associated vectors used for gene therapy of brain diseases: the role of immunological synapses in understanding the cell biology of neuroimmune interactions. Curr Gene Ther 2007; 7: 347-60.

[191] Muzyczka N, Warrington KH, Jr. Custom adeno-associated virus capsids: the next generation of recombinant vectors with novel tropism. Hum Gene Ther 2005; 16: 408-16.

[192] McFarland NR, Lee JS, Hyman BT, McLean PJ. Comparison of transduction efficiency of recombinant AAV serotypes 1,2,5, and 8 in the rat nigrostriatal system. J Neurochem 2009; 109: 838-45.

[193] Rabinowitz JE, Rolling F, Li C, et al. Cross-packaging of a single adeno-associated virus (AAV) type 2 vector genome into multiple AAV serotypes enables transduction with broad specificity. J Virol 2002; 76: 791-801.

[194] Wu Z, Asokan A, Samulski RJ. Adeno-associated virus serotypes: vector toolkit for human gene therapy. Mol Ther 2006; 14: 316-27.

[195] Ferrari FK, Samulski T, Shenk T, Samulski RJ. Second-strand synthesis is a rate-limiting step for efficient transduction by recombinant adeno-associated virus vectors. J Virol 1996; 70: 3227-34.

[196] McCarty DM. Self-complementary AAV vectors; advances and applications. Mol Ther 2008; 16: 1648-56.

[197] Wu J, Zhao W, Zhong L, et al. Self-complementary recombinant adeno-associated viral vectors: packaging capacity and the role of rep proteins in vector purity. Hum Gene Ther 2007; 18: 171-82.

[198] Clark KR, Liu X, McGrath JP, Johnson PR. Highly purified recombinant adeno-associated virus vectors are biologically active and free of detectable helper and wild-type viruses. Hum Gene Ther 1999; 10: 1031-9.

[199] Davidoff AM, Ng CY, Sleep S, et al. Purification of recombinant adeno-associated virus type 8 vectors by ion exchange chromatography generates clinical grade vector stock. J Virol Methods 2004; 121: 209-15.

[200] Kaludov N, Handelman B, Chiorini JA. Scalable purification of adeno-associated virus type 2,4 , or 5 using ion-exchange chromatography. Hum Gene Ther 2002; 13: 1235-43.

[201] Zolotukhin S, Potter M, Zolotukhin I, et al. Production and purification of serotype 1,2 , and 5 recombinant adeno-associated viral vectors. Methods 2002; 28: 158-67.

[202] Oehmig A, Fraefel C, Breakefield XO, Ackermann M. Herpes simplex virus type 1 amplicons and their hybrid virus partners, EBV, AAV, and retrovirus. Curr Gene Ther 2004; 4: 385-408.

[203] Lam PY, Breakefield XO. Hybrid vector designs to control the delivery, fate and expression of transgenes. J Gene Med 2000; 2: 395-408.

[204] Wang S, Di S, Young WB, Jacobson C, Link CJ, Jr. A novel herpesvirus amplicon system for in vivo gene delivery. Gene Ther 1997; 4: 1132-41.

[205] Sena-Esteves M, Saeki Y, Camp SM, Chiocca EA, Breakefield XO. Single-step conversion of cells to retrovirus vector producers with herpes simplex virus-Epstein-Barr virus hybrid amplicons. J Virol 1999; 73: 10426-39.

[206] Chiorini JA, Wendtner CM, Urcelay E, Safer B, Hallek M, Kotin RM. High-efficiency transfer of the T cell co-stimulatory molecule B7-2 to lymphoid cells using high-titer recombinant adenoassociated virus vectors. Hum Gene Ther 1995; 6: 1531-41.

[207] Feudner E, de Alwis M, Thrasher AJ, Ali RR, Fauser S. Optimization of recombinant adeno-associated virus production using an herpes simplex virus amplicon system. J Virol Methods 2001; 96: 97-105.

[208] Mamounas M, Leavitt M, Yu M, Wong-Staal F. Increased titer of recombinant AAV vectors by gene transfer with adenovirus coupled to DNA-polylysine complexes. Gene Ther 1995; 2: 42932.
[209] Vincent KA, Piraino ST, Wadsworth SC. Analysis of recombinant adeno-associated virus packaging and requirements for rep and cap gene products. J Virol 1997; 71: 1897-905.

[210] Booth MJ, Mistry A, Li X, Thrasher A, Coffin RS. Transfectionfree and scalable recombinant AAV vector production using HSV/AAV hybrids. Gene Ther 2004; 11: 829-37.

[211] Conway JE, Zolotukhin S, Muzyczka N, Hayward GS, Byrne BJ. Recombinant adeno-associated virus type 2 replication and packaging is entirely supported by a herpes simplex virus type 1 amplicon expressing Rep and Cap. J Virol 1997; 71: 8780-9.

[212] Fraefel C, Song S, Lim F, et al. Helper virus-free transfer of herpes simplex virus type 1 plasmid vectors into neural cells. J Virol 1996; 70: 7190-7.

[213] Logvinoff C, Epstein AL. A novel approach for herpes simplex virus type 1 amplicon vector production, using the Cre-loxP recombination system to remove helper virus. Hum Gene Ther 2001; 12: 161-7.

[214] Zaupa C, Revol-Guyot V, Epstein AL. Improved packaging system for generation of high-level noncytotoxic HSV-1 amplicon vectors using Cre-loxP site-specific recombination to delete the packaging signals of defective helper genomes. Hum Gene Ther 2003; 14: 1049-63.

[215] Johnston KM, Jacoby D, Pechan PA, et al. HSV/AAV hybrid amplicon vectors extend transgene expression in human glioma cells. Hum Gene Ther 1997; 8: 359-70.

[216] Giraud C, Winocour E, Berns KI. Recombinant junctions formed by site-specific integration of adeno-associated virus into an episome. J Virol 1995; 69: 6917-24.

[217] Kotin RM, Siniscalco M, Samulski RJ, et al. Site-specific integration by adeno-associated virus. Proc Natl Acad Sci USA 1990; 87: 2211-5.

[218] Linden RM, Winocour E, Berns KI. The recombination signals for adeno-associated virus site-specific integration. Proc Natl Acad Sci USA 1996; 93: 7966-72.

[219] Cortes ML, Oehmig A, Saydam O, et al. Targeted integration of functional human ATM cDNA into genome mediated by HSV/AAV hybrid amplicon vector. Mol Ther 2008; 16: 81-8.

[220] Oehmig A, Cortes ML, Perry KF, Sena-Esteves M, Fraefel C, Breakefield XO. Integration of active human beta-galactosidase gene $(100 \mathrm{~kb})$ into genome using HSV/AAV amplicon vector. Gene Ther 2007; 14: 1078-91.

[221] Bakowska JC, Di Maria MV, Camp SM, Wang Y, Allen PD, Breakefield XO. Targeted transgene integration into transgenic mouse fibroblasts carrying the full-length human AAVS1 locus mediated by HSV/AAV rep $(+)$ hybrid amplicon vector. Gene Ther 2003; 10: 1691-702.

[222] Schmidt M, Afione S, Kotin RM. Adeno-associated virus type 2 Rep78 induces apoptosis through caspase activation independently of p53. J Virol 2000; 74: 9441-50.

[223] Philpott NJ, Giraud-Wali C, Dupuis C, et al. Efficient integration of recombinant adeno-associated virus DNA vectors requires a $\mathrm{p} 5$ rep sequence in cis. J Virol 2002; 76: 5411-21.

[224] Liu Q, Perez CF, Wang Y. Efficient site-specific integration of large transgenes by an enhanced herpes simplex virus/adenoassociated virus hybrid amplicon vector. J Virol 2006; 80: 1672-9.

[225] Philpott NJ, Gomos J, Falck-Pedersen E. Transgene expression after rep-mediated site-specific integration into chromosome 19. Hum Gene Ther 2004; 15: 47-61.

[226] de Oliveira AP, Glauser DL, Laimbacher AS, et al. Live visualization of herpes simplex virus type 1 compartment dynamics. J Virol 2008; 82: 4974-90.

[227] Rizzuto G, Gorgoni B, Cappelletti M, et al. Development of animal models for adeno-associated virus site-specific integration. J Virol 1999; 73: 2517-26.

[228] Dutheil N, Yoon-Robarts M, Ward P, et al. Characterization of the mouse adeno-associated virus AAVS1 ortholog. J Virol 2004; 78: 8917-21.

[229] Amiss TJ, McCarty DM, Skulimowski A, Samulski RJ. Identification and characterization of an adeno-associated virus integration site in CV-1 cells from the African green monkey. J Virol 2003; 77: 1904-15.

[230] Cruchley AT, Murray PG, Niedobitek G, Reynolds GM, Williams DM, Young LS. The expression of the Epstein-Barr virus nuclear antigen (EBNA-I) in oral hairy leukoplakia. Oral Dis 1997; 3(Suppl 1): S177-9. 
[231] Black J, Vos JM. Establishment of an oriP/EBNA1-based episomal vector transcribing human genomic beta-globin in cultured murine fibroblasts. Gene Ther 2002; 9: 1447-54.

[232] Wang S, Vos JM. A hybrid herpesvirus infectious vector based on Epstein-Barr virus and herpes simplex virus type 1 for gene transfer into human cells in vitro and in vivo. J Virol 1996; 70: 8422-30.

[233] Wade-Martins R, Saeki Y, Chiocca EA. Infectious delivery of a 135-kb LDLR genomic locus leads to regulated complementation of low-density lipoprotein receptor deficiency in human cells. Mol Ther 2003; 7: 604-12.

[234] Wade-Martins R, Smith ER, Tyminski E, Chiocca EA, Saeki Y. An infectious transfer and expression system for genomic DNA loci in human and mouse cells. Nat Biotechnol 2001; 19: 1067-70.

[235] Wade-Martins R, Frampton J, James MR. Long-term stability of large insert genomic DNA episomal shuttle vectors in human cells. Nucleic Acids Res 1999; 27: 1674-82.

[236] Schulz TF, Cordes S. Is the Epstein-Barr virus EBNA-1 protein an oncogen? Proc Natl Acad Sci USA 2009; 106: 2091-2.

[237] Mulligan RC. The basic science of gene therapy. Science 1993; 260: 926-32.

[238] Nelson DM, Metzger ME, Donahue RE, Morgan RA. In vivo retrovirus-mediated gene transfer into multiple hematopoietic lineages in rabbits without preconditioning. Hum Gene Ther 1997; 8: 747-54.

[239] Short MP, Choi BC, Lee JK, Malick A, Breakefield XO, Martuza RL. Gene delivery to glioma cells in rat brain by grafting of a retrovirus packaging cell line. J Neurosci Res 1990; 27: 427-39.

[240] Culver KW, Ram Z, Wallbridge S, Ishii H, Oldfield EH, Blaese $\mathrm{RM}$. In vivo gene transfer with retroviral vector-producer cells for treatment of experimental brain tumors. Science 1992; 256: 1550-2.
[241] Takamiya Y, Short MP, Moolten FL, et al. An experimental model of retrovirus gene therapy for malignant brain tumors. J Neurosurg 1993; 79: 104-10.

[242] Isacson O, Breakefield XO. Benefits and risks of hosting animal cells in the human brain. Nat Med 1997; 3: 964-9.

[243] Rainov NG. A phase III clinical evaluation of herpes simplex virus type 1 thymidine kinase and ganciclovir gene therapy as an adjuvant to surgical resection and radiation in adults with previously untreated glioblastoma multiforme. Hum Gene Ther 2000; 11: 2389-401

[244] Ram Z, Culver KW, Oshiro EM, et al. Therapy of malignant brain tumors by intratumoral implantation of retroviral vector-producing cells. Nat Med 1997; 3: 1354-61.

[245] Shand N, Weber F, Mariani L, et al. A phase 1-2 clinical trial of gene therapy for recurrent glioblastoma multiforme by tumor transduction with the herpes simplex thymidine kinase gene followed by ganciclovir. GLI328 European-Canadian Study Group. Hum Gene Ther 1999; 10: 2325-35.

[246] Epstein AL, Manservigi R. Herpesvirus/retrovirus chimeric vectors. Curr Gene Ther 2004; 4: 409-16.

[247] de Felipe P, Izquierdo M, Wandosell F, Lim F. Integrating retroviral cassette extends gene delivery of HSV-1 expression vectors to dividing cells. Biotechniques 2001; 31:394-402, 4-5.

[248] Hampl JA, Camp SM, Mydlarz WK, et al. Potentiated gene delivery to tumors using herpes simplex virus/Epstein-Barr virus/RV tribrid amplicon vectors. Hum Gene Ther 2003; 14: 61126.

(c) de Oliveira and Fraefel; Licensee Bentham Open.

This is an open access article licensed under the terms of the Creative Commons Attribution Non-Commercial License (http: //creativecommons.org/licenses/by-nc/ 3.0/) which permits unrestricted, non-commercial use, distribution and reproduction in any medium, provided the work is properly cited. 